\title{
Agresja w perspektywie psychologicznej i filozoficznej. Przegląd wybranych teorii
}

\section{Ewa CZERWIŃSKA-JAKIMIUK*}

\begin{abstract}
Aggression in a psychological and philosophical perspectives. Review of selected theories: The article focuses on the phenomenon of aggression. From the philosophical perspective, the views of Jean-Jacques Rousseau and Thomas Hobbes are presented. From the psychological perspective, the definitions of aggression, with particular emphasis on the findings of Erich Fromm, and the main psychological theories: the instinct (Sigmund Freud, Konrad Lorenz), libido (John Dollard, Neal Miller, Leonard Doob, Ovral Mowrer, Robert Sears, Leonard Berkowitz) and social learning (Albert Bandura) are presented.
\end{abstract}

\section{KEYWORDS}

aggressive behaviour; congenital and acquired aggression; instincts theories; libido theories; learning theories

* Dr, adiunkt, Instytut Filozofii i Socjologii, Uniwersytet Pedagogiczny w Krakowie. E-mail: ewacz.up@gmail.com. 


\section{WPROWADZENIE}

Agresja degeneruje relacje międzyludzkie, ponieważ oznacza instrumentalne traktowanie drugiego człowieka. Tym samym jest w swej istocie zanegowaniem samej zasady człowieczeństwa, Kantowskiego imperatywu, który wymaga od partnerów, aby uznawali oni nawzajem swą ludzką godność i byli gotowi do przestrzegania w swych działaniach norm postępowania chroniących ich podmiotową autonomię (Paterek, 2001: 77).

Psychologowie, psychiatrzy, biolodzy, etolodzy i socjologowie od dawna stawiają pytania: Czy istnieje trwała natura ludzka, czy może zachowania człowieka są plastyczne i otoczenie może je dowolnie kształtować? Czy agresja jest wrodzona, nieuchronnie związana z ludzką naturą, biologicznie zdeterminowana cechami gatunku ludzkiego, czy też jest nabyta i powstaje w wyniku warunków środowiskowych? Czy za ludzką agresję odpowiadają czynniki natywistyczne, osobowościowo-sytuacyjne czy środowiskowo-społeczne? Niniejsze opracowanie dotyczy rozważań na temat agresji z perspektywy filozoficznej, ale przede wszystkim jest przeglądem głównych teorii psychologicznych na temat jej genezy (teorie instynktu, popędu i uczenia się) ${ }^{1}$.

Zaznaczyć należy, iż przytoczone powyżej pytania mają wymiar filozoficzny i towarzyszą filozofii od wieków. W dyskusję na temat źródeł agresji wpisują się poglądy Jeana-Jacques'a Rousseau (agresja nabyta) i Thomasa Hobbesa (agresja w naturze ludzkiej).

Rousseau, wprowadzając pojęcie „szlachetnego dzikusa”, zakłada, iż człowiek w swoim naturalnym stanie jest dobry, szczęśliwy, łagodny, wolny, a społeczeństwo poprzez różnego rodzaju restrykcje wyzwala $\mathrm{w}$ nim agresywność i tym samym degraduje go (Rousseau, 1966). Rousseau wyrażał przekonanie, iż natura ludzka jest pod przemożnym i deformującym wpływem istniejących instytucji społecznych oraz politycznych, że jej autentyczne potrzeby i pragnienia powinny być fundamentami moralności, a poziom ich zaspokojenia kryterium oceny instytucji społecznych (MacIntyre, 2000: 238). Według Rousseau człowiek jest dobry jedynie w stanie natury, ponieważ tylko w nim postępuje zgodnie ze swoimi uczuciami i wrodzonymi skłonnościami oraz tylko wtedy istnieje równość między ludźmi. Natomiast kultura i cywilizacja hamują naturalny rozwój człowieka. Należy stworzyć więc taką kulturę i cywilizację, które odpowiadają i sprzyjają naturalnemu rozwojowi jednostki oraz społeczeństwa. Ważne jest tutaj, po pierwsze, państwo, w którym podstawą porządku jest prawo i moralność, a którego warunkiem powstania jest umowa społeczna, po drugie zaś, deprecjacja rozumu i prymat uczuć, które należy kształtować

${ }^{1} \mathrm{~W}$ skróconej formie autorka pisała o definicjach agresji oraz teoriach popędu i uczenia się w artykule: Czerwińska-Jakimiuk, E. (2020). Agresja i przemoc wobec zwierząt. Uwarunkowania psychologiczne (s. 227-241). W: D. Probucka (Red.). Etyczne potępienie myślistwa. Kraków: Universitas. 
$\mathrm{w}$ procesie wychowania. Do niezbędnych zadań realizowanych w tym procesie należą: swobodny rozwój naturalnych skłonności dziecka, poszanowanie dla natury, samodzielność, zamiłowanie do cnoty, wierność temu, co przez prawo natury i tak zwany głos serca uznane jest za dobre (Legowicz, 1967: 382-385; Baczko, 2009).

Z kolei Hobbes zakładał, iż jednostka ludzka z natury jest zła; powstrzymać jej agresję i skłonić do wysublimowania naturalnych instynktów może wyłącznie państwo, stojące na straży prawa i zasad umowy społecznej. Zdaniem Hobbesa motywów życia społecznego należy szukać w dwóch zasadach, które są źródłem i podstawą ludzkiego postępowania - egoistycznym dążeniu do samozachowania (cupiditas naturalis) oraz szukaniu własnej korzyści (ratio naturalis). Innymi słowy podstawowe motywy ludzkie to: pragnienie panowania (władzy) i pragnienie uniknięcia śmierci (strach przed nią). Według Hobbesa jednostka ludzka nie jest zdolna ze swej natury do życia społecznego, a mając kontakty z innymi, dąży do tego, aby to oni przysparzali jej zaszczytów oraz korzyści. $Z$ natury więc człowiek jest wrogo nastawiony do drugiego człowieka i uznaje tylko prawo silniejszego. Można przyjąć, iż jest wręcz aspołeczny i pozostaje w ciągłym stanie wojny wszystkich przeciw wszystkim - bomo bomini lupus. Z drugiej strony jednak każdy pragnie dla siebie dobra, co implikuje zgodnie z prawem natury poszukiwanie sprzymierzeńców oraz pokoju tam, gdzie jest możliwy (a jeśli nie jest, to czerpanie korzyści z wojny) czy dzielenie się uprawnieniami z innymi (tak zwana umowa). Aby ten stan umowy utrzymać, konieczne jest podporządkowanie się jednej instytucji, państwu (Hobbes, 1954; Legowicz, 1967: 321-322; MacIntyre, 2000: 179-181).

Współcześnie tematem natury ludzkiej, w tym genezy agresji i zachowań agresywnych, zajmują się, jak zaznaczono wcześniej, przedstawiciele różnych dyscyplin naukowych. Zauważyć można jednak, że z racji odmienności przyjmowanych założeń antropologicznych i wielości udzielanych przez naukowców odpowiedzi dyskusja na temat źródeł agresji nie utraciła wymiaru filozoficznego.

\section{DEFINICJA AGRESJI}

Agresja w psychologii definiowana jest najczęściej jako zachowanie ukierunkowane na zadanie cierpienia, wyrządzenie szkody, bólu, krzywdy lub przykrości innemu człowiekowi (lub innej istocie żyjącej), który jest motywowany do uniknięcia tego typu doznań (Frączek, 1979; Stach, 1989; Aronson, 1995; Krahé, 2006; Wojciszke, 2007). W zbliżony sposób wypowiada się Jeno Ranschburg (Ranschburg, 1993), przyjmując, iż agresja to zamierzone (mniej lub bardziej umyślne) działanie (w formie otwartej lub symbolicznej), które ma na celu wyrząadzenie komuś lub czemuś szkody, straty, bólu. 
Możemy wyróżnić dwa rodzaje agresji: emocjonalną i instrumentalną. Pierwsza, nazwana gniewną (wrogą), jest celem samym w sobie - na przykład wyrządzenie szkody osobie, do której żywi się negatywne emocje i chce się wywołać jej cierpienie. Druga, instrumentalna, stanowi środek do osiągnięcia celu - mogą to być między innymi przestępstwa z motywacji rabunkowej/ekonomicznej, niektóre gry sportowe, wykonywane zawody i zachowania rekreacyjne - hobby. Zdarza się czasami, że te dwa rodzaje agresji łączą się ze sobą - na przykład zawodnik w grze zespołowej boleśnie fauluje osobę z drużyny przeciwnej, ponieważ chce zwiększyć szanse wygranej swojej drużyny oraz darzy faulowanego antypatią i z premedytacją zamierza zadać mu ból czy wyrządzić krzywdę. Kontrowersje pojawiają się czasem także w wypadku wykonywania niektórych zawodów, sprawowania funkcji czy realizowania hobby, na przykład żołnierz, policjant, rzeźnik, rekreacyjny myśliwy zadają ból, powodują utratę dobrostanu czy pozbawiają życia człowieka lub inną istotę żyjącą w związku z wykonywanymi czynnościami, a jednocześnie odczuwają przyjemność. Motywowane to może być wieloma czynnikami zarówno o charakterze osobowościowo-sytuacyjnym, społecznym, biologiczno-mózgowym (na przykład stymulacja ośrodka nagrody/przyjemności w mózgu, uzależnienie od dopaminy), jak i stereotypami oraz uprzedzeniami wobec określonych grup.

Analizując zjawisko agresji, należy rozróżnić następne dwa jej rodzaje: agresję ujmowaną jako pojedyncze zachowanie oraz agresję jako względnie stałą cechę osobowości. Pierwszy rodzaj rozumiany jest jako „reakcja dostarczająca szkodliwych bodźców innemu organizmowi” (Krahé, 2006: 16). Drugi natomiast, odnoszący się do agresji jako utrwalonej dyspozycji osobowościowej, utożsamiany z agresywnością, definiowany jest jako „właściwość jednostki, decydująca o skłonności do zachowań agresywnych i ich częstego manifestowania" (Stanik, Roszkowska, \& Kucharewicz, 2006: 82, za: Haś, 2008: 61).

$\mathrm{Na}$ gruncie polskim na znaczenie podziału pomiędzy agresją będącą pojedynczym aktem a agresją będącą stałą cechą indywidualną jednostki wskazał Adam Frączek (Frączek, 1979; Frączek, 2002: 45-64). Stwierdził on, iż agresywna reakcja stanowi uzewnętrznienie wywołanego sytuacyjne stanu emocjonalno- motywacyjnego. Agresja (agresywność) jako utrwalona skłonność oznacza natomiast wewnętrzną gotowość jednostki do uruchamiania tego typu zachowań, które wywodzą się z jej wadliwie ukształtowanej osobowości.

W kontekście powyższych rozważań nie sposób nie odnieść się do ustaleń Ericha Fromma na temat agresji (Fromm, 1998; Fromm, 2015). Zarówno bowiem dotyczą one filozoficznego pytania o naturę ludzką, rozważań psychologicznych, jak i mają charakter integracyjny - są próbą uporządkowania prawie wszystkich aspektów zachowań agresywnych (Hołyst, 2016: 743). I tak, zdaniem Fromma charakter jednostki kształtuje się poprzez powiązanie ze światem oraz nawiązywanie relacji z innymi osobami - z uwzględnieniem procesu 
asymilacji i socjalizacji. W tej perspektywie agresja jednostki jawi się jako efekt czynników zewnętrznych, a wzrost liczby zachowań agresywnych tkwi w rozpadzie więzi międzyludzkich (Przybysz-Zaremba, 2015: 320).

Fromm dokonał rozróżnienia między agresją niezłośliwą, naturalną, powiązaną z instynktem samozachowawczym, a agresją złośliwą, opartą na destrukcyjności i okrucieństwie. Tym samym podzielił zachowania agresywne na biologicznie adaptacyjne (obronne, służące ochronie znaczących wartości i życia ludzkiego) oraz biologicznie dezadaptacyjne (destrukcyjne, pełne okrucieństwa). W drugim wypadku agresja nie jest wytworzona filogenetycznie, ale przejawiają ją osoby, u których został wykształcony odpowiedni typ charakteru. Te orientacje charakterologiczne to: sadyzm, nekrofilia, narcyzm ${ }^{2}$ i kazirodcza fiksacja. Innymi słowy: miłość śmierci, złośliwy narcyzm i symbiotyczna kazirodcza fiksacja (ściśle związana z narcyzmem), które przyjmując ekstremalne formy - w przeciwieństwie do „syndromu wzrostu”, na który składają się biofilia, miłość (bliźniego, obcego, natury), niezależność, wolność - tworzą „syndrom rozkładu” (Fromm, 2015: 16, 132-134). Fromm stwierdza: „Osoba cierpiąca na ten syndrom jest niezaprzeczalnie złym człowiekiem, ponieważ zdradza sprawę życia i rozwoju i staje się czcicielem śmierci i kalectwa" (Fromm, 2015: 126).

Sadyzm i nekrofilia to zdaniem Fromma (Fromm, 1998; Fromm, 2015) dwie podstawowe formy ludzkiej destrukcyjności. Istota sadyzmu polega na posiadaniu absolutnej, niczym nieograniczonej kontroli nad światem ludzi: poniżaniu, zadawaniu bólu i cierpienia, pozbawianiu życia. Nekrofilia natomiast, zgodnie z sugestią hiszpańskiego filozofa Miguela de Unamuno ${ }^{3}$, dotyczy dążenia do przekształcenia wszystkiego, co żywe, w pozbawione życia oraz fascynacji wszystkim, co martwe, zepsute, zniszczone. Charakterystyczne jest tu przekonanie jednostki, iż wszelkie konflikty i problemy można rozwiązać poprzez zastosowanie siły, przemocy, a tym samym zmierzanie do destrukcji.

Narcyzm złośliwy to kolejne potencjalne źródło zachowań agresywnych. Fromm pisze:

jeżeli narcyzm (jednostki) zostanie zagrożony, groźba w istotnym sensie wymierzona jest również przeciwko niej samej. Kiedy inni ranią jej narcyzm, lekceważąc ją, krytykując, dowodząc omyłek, pokonując w rozmaitych grach [...], osoba narcystyczna zazwyczaj reaguje intensywnym gniewem lub nawet wściekłością, niezależnie od tego, czy to okazuje, czy nie, a nawet, czy jest tego świadoma [...] i często czuje potrzebę zemsty (Fromm, 1998: 222).

${ }^{2}$ Fromm rozwija odkrywcze ustalenia Sigmunda Freuda na temat zjawiska narcyzmu zob. Freud, 2020.

${ }^{3}$ Podczas przemówienia Miquela de Unamuno na Uniwersytecie w Salamance w 1936 roku frankistowski generał José Millán-Astray krzyknął: „Viva la muerte”. Okrzyk ten Unamuno określit jako nekrofiliczny — szerzej na ten temat: Fromm, 1998; Fromm, 2015. 
Ten rodzaj narcyzmu nie jest poddawany samoregulacji przez kontakt z rzeczywistością, a jego niebezpieczeństwo polega na braku racjonalnego osądu rzeczywistości i braku obiektywizacji.

Fromm szczególną uwagę poświęca transformacji narcyzmu indywidualnego w zbiorowy (grupowy), który w swej złośliwej formie stanowi ważne źródło ludzkiej agresji i przemocy (Fromm, 1998; Fromm, 2015). Badacz twierdzi:

narcyzm grupowy wzmacnia solidarność i spójność grupy oraz ułatwia manipulowanie nią poprzez odwoływanie się do narcystycznych uprzedzeń [...] przysparza on zadowolenia członkom grupy, którzy nie mają zbyt wielu powodów, by czuć się dumni oraz wartościowi [...]. Własna grupa staje się obrońcą ludzkiej godności, przyzwoitości, moralności i słuszności. Tamtej przypisuje się iście diabelskie właściwości: staje się zdradziecka, bezwzględna, okrutna i z gruntu nieludzka (Fromm, 1998: 223, 224, 225).

Kazirodcza fiksacja natomiast to rodzaj związku symbiotycznego, który hamuje rozwój człowieka jako osoby. Fromm rozszerzył to kluczowe Freudowskie pojęcie, odnosząc je nie tylko do figury matki, ale również do innych osób lub grup jednostek. Innymi słowy, jego zdaniem adresatem kazirodczej fiksacji może być rodzina, klan, rasa, naród, partia i każda inna organizacja umożliwiająca jednostce identyfikację. Negatywne cechy takiej fiksacji to niemożność stworzenia czy podtrzymania głębszych relacji z człowiekiem innym niż ci, z którymi wiążą jednostkę symbiotyczne więzi, niezdolność kochania oraz nieumiejętność zachowania własnej niezależności i integralności oraz wykształcenia autonomii. W swej złośliwej formie fiksacja ta prowadzi do podobnych rezultatów, jak nekrofilia i narcyzm złośliwy (Fromm, 2015: 109-134; por. Przybysz-Zaremba, 2015: 320, 321). Fromm pisze:

istnieje bliskie pokrewieństwo pomiędzy kazirodczą fiksacją a narcyzmem [...]. Można to łatwo zaobserwować, kiedy narcyzm indywidualny jest przekształcany w narcyzm zbiorowy [...] i właśnie ta szczególna mieszanina może nam wyjaśnić siłę i irracjonalność wszelkich nacjonalistycznych, rasowych, religijnych i politycznych fanatyzmów [...]. Gdy symbioza kazirodcza oraz narcyzm przyjmą najbardziej archaiczne formy, dołącza się do nich nekrofilia [...] możemy wówczas mówić o „syndromie rozkładu” [...]. Reprezentuje on kwintesencję zła; stanowi zarazem najgroźniejsze zjawisko patologiczne oraz źródło najzłośliwszych niszczycielskich i perwersyjnych działan (Fromm, 2015: 126, 33).

\section{TEORIE INSTYNKTU}

W teorii instynktu (Sigmund Freud, Konrad Lorenz, William McDougall) agresja jest postrzegana jako zachowanie wrodzone, zdeterminowane biologicznie, powstałe w drodze ewolucji, konieczne do zachowania gatunku, domagające się rozładowania i oporne na wpływy zewnętrzne oraz uczenie się. Socjobiologia 
(Edward Wilson) i psychologia ewolucyjna (David Buss) natomiast kładą nacisk na długoterminowy rozwój agresji w kontekście ewolucji, zarówno u zwierząt, jak i ludzi. Zachowania agresywne są ukierunkowane przede wszystkim na zwalczanie zagrożenia i rywalizację seksualną, co traktowane jest jako zbiór zachowań o charakterze przystosowawczym i zwiększającym osiągnięcie sukcesu reprodukcyjnego (Krahé, 2006: 34).

Poniżej zostaną pokrótce omówione dwie teorie agresji: Freuda i Lorenza. Należy odwołać się tutaj do hydraulicznej koncepcji agresji, która przyjmuje, że energia agresywna jest stale i samoistnie wytwarzana oraz gromadzona wewnątrz organizmu. Ciągły jej napływ powoduje konieczność rozładowania poprzez zachowania agresywne, które są skierowane na zewnątrz. W tym ujęciu obecność agresji jest czymś nieuchronnym zarówno u ludzi, jak i zwierząt (Wojciszke, 2007: 148-149).

Freud zakłada istnienie w człowieku dwóch sił: Erosa (instynktu życia) i Thanatosa (instynktu śmierci). Na skutek „ścierania się” ze sobą muszą one być uwalniane na zewnątrz, gdyż są źródłem trwałego konfliktu wewnętrznego. Zakładając znaczną kumulację energii „śmierci” w organizmie, doszłoby do czynów autodestrukcyjnych (samobójstw, zaburzeń psychicznych), tak więc organizm co jakiś czas musi uwalniać się od jej destrukcyjnej siły i wyrzucać ją na zewnątrz w postaci zachowań agresywnych. Spełnia to funkcję ochronną dla równowagi psychicznej jednostki i jest elementem niezbędnym dla przeżycia. Społeczeństwo według Freuda odgrywa znaczącą rolę w kontrolowaniu instynktu śmierci, umożliwiając jednostce sublimacje - przekształcanie destrukcyjnej energii w zachowania aprobowane społeczne, czasami wręcz użyteczne (Freud, 1975; Aronson, 1995: 304-305; Krahé, 2006).

Według Lorenza (Lorenz, 1972) człowiek jest wytworem mechanizmów ewolucji, a agresja zarówno u zwierząt, jak i ludzi jest wrodzona, ma charakter spontaniczny i zostaje automatycznie wzbudzona poprzez zaistnienie w otoczeniu tak zwanych wyzwalaczy lub zahamowana na skutek tak zwanych inhibitorów. Agresja jest zachowaniem nieuchronnie przejawianym przez wszystkie żyjące istoty - ludzi i zwierzęta. Lorenz w swoim podejściu wykorzystał, po pierwsze, argumenty o adaptacyjnych korzyściach agresji wewnątrzgatunkowej (na przykład samiec walczy z innymi samcami o samicę, a walka ta zwiększa prawdopodobieństwo, że zapłodni ją najsilniejszy, zapewniając sobie sukces reprodukcyjny - silniejsze i lepsze geny w przyszłych pokoleniach), po drugie, bazowat na obserwacji ryb, w tym agresywnego gatunku tropikalnych pielęgnic, oraz ptaków i gadów, u których niejednokrotnie występują zautomatyzowane i niezmienne sekwencje zachowań agresywnych, niewymagające $\mathrm{w}$ żadnym stopniu uczenia się. Ponadto badacz ten zakładał, iż agresja jest istotnym elementem organizacji instynktów chroniących życie. Jest ona „tak zwanym złem”, ponieważ wpływa korzystnie na prawidłowe rozmieszczenie osobników danego gatunku na całym terytorium, tworzenie się hierarchii społecznej, 
selekcję obrońców stada, jako że do rozrodu dopuszczane są z reguły osobniki najsilniejsze (Lorenz, 1972; szerzej na ten temat: Ziółkowski, 2015).

Elliot Aronson (Aronson, 1995: 310, 311) w tym kontekście przytacza ustalenia psychologa i antropologa M.F. Ashley'a Montagu oraz geografa, anarchisty i przedstawiciela tak zwanego darwinizmu rosyjskiego Piotra Kropotkina. Według Montagu pogląd wyrażony w monografii On being buman z 1950 roku, iż konflikt jest nieuniknionym prawem życia, wynika $\mathrm{z}$ nadmiernego uproszczenia i niewłaściwej interpretacji teorii Charlesa Darwina. Przykładowo w czasie rewolucji przemysłowej ludziom bogatym łatwiej było dokonać racjonalizacji wyzysku, przyjmując założenie dotyczące życia jako walki o przetrwanie, gdzie zwyciężają najsilniejsi, jakoby najlepiej przystosowani. Rozumowanie takie może stać się „samospełniającym się proroctwem” oraz sprzyjać podtrzymywaniu zachowań agresywnych i skrajnie rywalizacyjnych.

Kropotkin natomiast w 1902 roku w dziele Pomoc wzajemna jako czynnik rozwoju społeczeństw oraz w Etyce z 1922 roku dochodzi do wniosku, iż dla przetrwania wielu form życia szczególne znaczenie mają współdziałanie i wzajemna pomoc. Uważał się on za kontynuatora myśli Darwina, jednak jego poglądy ewolucyjne były odmienne od poglądów zdecydowanej części darwinistów ze szczególnym uwzględnieniem Thomasa Malthusa. Kropotkin zakładał, że zachowania altruistyczne występują w przyrodzie tak samo często jak egoistyczne, podał też wiele przykładów współpracy wewnątrzgatunkowej i międzygatunkowej, zarówno w zwierzęcych, jak i ludzkich społecznościach (Drabiński, 2019).

Pomimo niezaprzeczalnego wkładu naukowego Freuda i Lorenza ${ }^{4}$ (oraz innych etologów - Nicolasa Tinbergena, Karla von Frischa) wobec ich teorii instynktu wysuwano szereg zarzutów. Krytycy (Fromm, 1998; Aronson, 1995; Wojciszke, 2007; Krahé, 2006; Gaberle, Błachut, \& Krajewski, 2000) zwracali uwagę na następujące wady tez Freuda (że agresja to przetworzony instynkt samozniszczenia charakterystyczny dla wszystkich ludzi) i Lorenza (że u wszystkich zwierząt istnieją wrodzone, oporne na wpływy zewnętrzne wzorce zachowań agresywnych):

- brak naukowej metodologii i nieweryfikowalność (brak możliwości testowania) przyjętych założeń - w wypadku tez Freuda;

- obserwacje badaczy, że nie pojawiają się zachowania agresywne uważane przez Lorenza za typowe dla danego gatunku (szczególnie wówczas, gdy potrzeby reprezentantów tego gatunku były zaspokojone - zob. eksperymenty Zing Yang Kuo z kotami i szczurami) oraz że natężenie agresji może być silnie modyfikowane przez wpływy środowiska oraz indywidualne doświadczenia danego osobnika;

${ }^{4}$ Podkreślić należy, iż zdecydowaną część naszej wiedzy na temat zachowań zwierząt zawdzięczamy Lorenzowi. 
- brak wystarczających empirycznych uzasadnień dla tezy, iż zwierzęta (a tym bardziej ludzie) dążą do agresji oraz że u wyższych gatunków zwierząt mamy do czynienia ze spontanicznym wytwarzaniem agresywnej energii, a w wyniku jej kumulacji z koniecznością rozładowania bez najmniejszej prowokacji z zewnątrz; część obserwacji zwierząt prowadzi do wniosku, iż agresja ma charakter unikanego stresu i niejednokrotnie jest wykazywana w ostateczności;

- brak analizy zachowania plastycznego, które jest właściwe człowiekowi i zwierzętom o zaawansowanych procesach psychicznych (Pisula, 2007: 203);

- obserwacje antropologów, że istnieją społeczności ludzkie nieprzejawiające zachowań agresywnych (na przykład plemiona Indian Pueblo Zuni, Arapeszów z Nowej Gwinei, Pigmeje z Afryki, Tasadeyowie z Filipin, Irokezi przed przybyciem Europejczyków).

\section{TEORIE POPĘDU}

Zachowanie agresywne w teorii tej jest traktowane jako rozładowanie popędu, który stanowi rezultat oddziaływania czynników sytuacyjnych, a sposób rozładowania go zależy od procesów związanych z uczeniem się.

W ramach teorii popędu zostaną omówione dwa podejścia dotyczące agresji: Johna Dollarda, Neala Millera, Leonarda Dooba, Orvala Mowrera i Roberta Searsa oraz Leonarda Berkowitza, które najogólniej rzecz ujmując, posługują się terminem "frustracja”. Frustracja to nieprzyjemny stan napięcia psychicznego, powstającego wówczas, gdy dążąc do celu / chcąc zaspokoić jakąś potrzebę, napotykamy przeszkodę - zazwyczaj o charakterze zewnętrznym, wyłaniającą się z otoczenia. Frustracja może mieć tym samym charakter indywidualny/ jednostkowy i społeczny, obejmujący swym zasięgiem grupy, społeczeństwa (Aronson, 1995).

Dollard, Miller i wsp. (Dollard et al., 1961) w teorii frustracji-agresji z 1939 roku opisują agresję jako popęd ukierunkowany na cel. Przyjmują oni, po pierwsze, że za wystąpienie agresji odpowiada stan frustracji, po drugie, że frustracja stanowi przyczynę zachowania agresywnego. Badacze definiowali ją nie jako stan psychiczny, lecz jako przeszkodę, która pojawia się na drodze do zrealizowania wyznaczonego celu; podstawowym czynnikiem powstrzymującym agresję było antycypowanie kary i obawa przed nią. Jeżeli strach przed karą jest znaczący, to zazwyczaj następuje przemieszczenie agresji lub zmiana jej postaci (Wojciszke, 2007). W pierwszym wypadku mamy do czynienia ze skierowaniem jej na inny obiekt zagrożony słabszą karą lub tak zwany bezpieczny, gdzie w ogóle nie występuje zagrożenie karą, na przykład matka krzyczy i karze dziecko, a jej agresję wzbudził przełożony w pracy. W drugim natomiast dochodzi do jej zastąpienia inną reakcją agresywną, zdecydowanie słabiej zagrożoną karą, na przykład 
zamiast ataku na dominującą kontrolującą matkę mężczyzna „snuje” opowieści o niższości kobiet.

Dość wcześnie pojawiły się głosy krytyczne wobec powyższych założeń. Chodziło o dwa następujące aspekty: na frustrację można reagować inaczej niż agresją oraz nie każde zachowanie agresywne jest spowodowane frustracją. Reakcją również może być: płacz, smutek, złość, obniżenie nastroju, apatia, wycofanie się, depresja, używanie środków psychoaktywnych, zaburzenia psychosomatyczne, konstruktywne manipulowanie środkami (próba osiągnięcia tego samego celu za pomocą innych działań) i celami (zmiana celu na również atrakcyjny, a łatwiejszy do osiągnięcia). Następstwem frustracji może być także fiksacja (uporczywe powtarzanie reakcji, nieprzynoszące pożądanych skutków) i regresja (cofnięcie się do wcześniejszych faz rozwoju - prymitywizacja i infantylizacja zachowań). Skłoniło to badaczy, przede wszystkim Millera (Krahé, 2006: 38), do modyfikacji założeń. Po pierwsze, uznano, iż frustracja stwarza podniety do wielu różnych typów reakcji, między innymi do jakiejś formy agresji. Po drugie, przyjęto istnienie wielu zmiennych pośredniczących, co pozwoliło na wyjaśnienie zjawiska agresji przemieszczonej — zmiana obiektu na bardziej dostępny, psychologicznie bezpieczny i budzący mniejszy lęk (Gaberle, Błachut, \& Krajewski, 2000: 284, 285).

Berkowitz (Berkowitz, 1988: 3-12) poddał modyfikacji powyższą teorię. Wprowadził bowiem do klasycznego schematu frustracja-agresja silną emocję pobudzającą - gniew, element poznawczy zawierający interpretację sytuacji przez jednostkę, oraz tak zwane sygnały wywoławcze agresji (bodźce związane zarówno z przykrym lub bolesnym doświadczeniem emocjonalnym, jak i z pozytywnym wzmocnieniem za zachowanie agresywne). W konsekwencji, aby doszło do zachowania agresywnego, niezbędne jest pojawienie się następujących czynników:

- zadatków wewnętrznych (wrodzonych lub nabytych w procesie socjalizacji),

- frustracji,

- zareagowania na doznawaną frustrację gniewem bądź zaistnienie negatywnego pobudzenia emocjonalnego - gniewu bez pojawienia się frustracji,

- czynnika ostatecznie wyzwalającego agresję, tak zwanego spustowego, który bezpośrednio budzi skojarzenia z walką, biciem, zabijaniem, na przykład kusza, nóż, pistolet, kij, lub kojarzony jest z nią pośrednio, na przykład wąż, który doprowadza gaz do kuchenki, wyzwala skojarzenie z wężem, sznurem, którym bito potencjalnego agresora w dzieciństwie.

Podkreślić należy, że im więcej wymienionych powyżej czynników będzie występować u jednostki w danej sytuacji, tym bardziej prawdopodobna stanie się jej agresywna reakcja. Szczególnego znaczenia nabiera tutaj negatywne pobudzenie emocjonalne, które jest interpretowane przez osobę jako gniew.

Wypada zaznaczyć, iż ustalenia Berkowitza (pomimo zarzutów dotyczących niejasności pojęcia sygnału wywoławczego oraz o charakterze metodologicznym) 
znalazły potwierdzenie empiryczne, zarówno jeśli chodzi o przeprowadzane eksperymenty dotyczące tak zwanego efektu broni, jak i o analizę akt policyjnych czy sądowych odnośnie do przebiegu zdarzeń w przestępstwach z użyciem agresji i przemocy.

W jednym z eksperymentów biorących w nim udział studentów podzielono na dwie grupy i poddano ich frustracji, wprowadzając osobę gościa-autorytetu, który specjalnie przyjechał do nich z zamiarem przeprowadzenia zajęć wykładowych. Na początku zachowywał się on kulturalnie, był sympatyczny, zachęcał słuchaczy do dyskusji i swobodnego wypowiadania się, z czasem jednak stawał się arogancki, niemiły i wyśmiewał wypowiedzi studentów oraz kpił z nich. Frustracja dotyczyła tutaj przede wszystkim poczucia własnej wartości, potrzeby szacunku i uznania. Jedna grupa uczestników była frustrowana w sali ze standardowym umeblowaniem, druga natomiast w pomieszczeniu, gdzie na jednej ze ścian były gabloty, w których umieszczono różne rodzaje broni: noże, pistolety, kije, strzelby, kusze czy miniatury armat (automatycznie kojarzące się z wojną, walką, biciem innych i zabijaniem). Później obie grupy miały możliwość odreagowania zaistniałej, frustrującej sytuacji. Okazało się, że studenci, których poddawano frustracji w sali z bronią umieszczoną w gablotach, wykazywali większą chęć rozładowania napięcia i negatywnych emocji, w tym gniewu, za pomocą zachowań agresywnych i odwetowych ${ }^{5}$.

W końcu rozważań na temat związku frustracji i gniewu z agresją można przedstawić następujące ustalenia psychologów. Przyjmują oni:

- po pierwsze, że nie tylko frustracja determinuje agresję, ale może to czynić cały zestaw innych bodźców (atak fizyczny bądź werbalny, bodźce przykre i drażniące);

- po drugie, znamienne jest znaczenie reakcji emocjonalnych (głównie gniewu) jako czynników wpływających na przebieg reakcji frustracja-agresja;

- po trzecie, inne emocje poza gniewem także zwiększaja prawdopodobieństwo wystąpienia agresji wskutek działania frustracji), a typy frustracji - te wywołane zagrożeniem ego i obrazu własnej osoby - nasilają tendencje do zachowań agresywnych (Buss \& Perry, 1992; Coffer \& Appley, 1972; Krahé, 2006; Kubacka-Jasiecka, 2010; Wolska, 2002; Terelak, 2001).

\section{TEORIA UCZENIA SIE}

W teorii tej kładzie się nacisk na rozumienie agresji jako skutku uczenia się w ciągu życia jednostki ze szczególnym uwzględnieniem dzieciństwa i wieku dojrzewania. Albert Bandura (Bandura, 1973; Bandura, 2007) ze

\footnotetext{
${ }^{5} \mathrm{~W}$ literaturze fachowej opisywane są różne wersje powyższego eksperymentu — na gruncie opracowania wybrano najprostszy schemat.
} 
współpracownikami badał wpływ środowiska (rodzinnego, szkolnego, rówieśniczego, subkulturowego, społeczności lokalnej, podkultury, mass mediów) na występowanie zachowań agresywnych. Przyjmował on, że zachowanie agresywne podlega wyuczeniu w taki sam sposób, jak każde inne. Proces uczenia odbywa się następująco:

- obserwacja przez jednostkę (na przykład dziecko) zachowania agresywnego;

- obserwacja osoby tak zwanego modela agresywnego, który za zachowanie agresywne uzyskuje nagrodę, a nie zostaje ukarany;

- naśladownictwo;

- wyuczenie - częste przejawianie zachowań agresywnych lub agresja jako stała cecha osobowości.

W klasycznym eksperymencie z lalką Bobo ${ }^{6}$ dzieci obserwowały mężczyznę, który został zaproszony do przedszkola i przyniósł ze sobą lalkę. W pewnym momencie zaczął wykazywać zachowania agresywne wobec niej - krzyczał na nią, bił ją, uderzał nią o kanty stołu (w zależności od wersji eksperymentu). Po obserwacji tego eskalującego agresję zachowania mężczyzny - tak zwanego modela - dzieci podzielono na trzy grupy. W pierwszej z nich wychowawca nie skomentował zachowania mężczyzny - dzieci dołączyły więc do codziennych zajęć/zabaw; w drugiej został on nagrodzony - na przykład pochwalono go i dano mu czekoladę; w trzeciej grupie został on ukarany - na przykład zwrócono mu uwagę, uznano, że jego zachowanie wobec lalki Bobo jest godne potępienia, i wyproszono go z przedszkola. Następnie poddano obserwacji dzieci w trakcie zabawy, utrzymując nadal podział na trzy grupy - w pierwszej występowały zachowania agresywne i nieagresywne dzieci wobec siebie oraz zabawek, w drugiej zauważono znaczący wzrost zachowań agresywnych, w trzeciej natomiast zdarzały się one incydentalnie. Po wprowadzeniu do zabawy lalki Bobo niektóre dzieci obserwujące nagrodzenie modela agresywnego (grupa 2) wymyślały bardziej zintensyfikowane, niejednokrotnie okrutniejsze, wręcz sadystyczne formy znęcania się nad lalką (Aronson, 1995).

Podkreślić należy, iż Bandura i jego współpracownicy szczególną rolę przywiązywali do agresji i przemocy przedstawianej w mass mediach (na przykład bajki dla dzieci, filmy, kreskówki, komiksy, współcześnie na pewno byłaby to część gier komputerowych, w których gracz nie tylko obserwuje przemoc, ale sam zabija, torturuje i może przywracać życie). Implikuje to u niektórych osób (w szczególności dzieci i adolescentów) - po pierwsze - wyuczenie agresji i późniejsze stosowanie przemocy wobec innych, po drugie - zjawisko desensytyzacji (odwrażliwienia) na krzywdę, ból, cierpienie, śmierć, po trzecie - deficyty $\mathrm{w}$ rozwoju emocjonalnym i moralnym. W dalszym życiu u takich osób można zauważyć brak uczuć wyższych i zdolności współczucia innym, chłód

\footnotetext{
${ }^{6} \mathrm{~W}$ literaturze fachowej opisywane są różne wersje eksperymentu z lalką Bobo — na gruncie opracowania wybrano najprostszy schemat.
} 
emocjonalny, brak empatii lub niski jej poziom bądź jej selektywność oraz słabe przyswojenie wartości prospołecznych (Poznaniak, 2001).

Tacy badacze jak Leonard Berkowitz czy Matthew Hogben (Krahé, 2006: 95-97) dokonali szczegółowej analizy i opisu warunków, które mają wpływ na fakt, iż prezentowana $\mathrm{w}$ mediach agresja i przemoc znajdą swoją reprezentację i zastosowanie w późniejszych zachowaniach osób oglądających:

- przypisywanie agresywnego znaczenia obserwowanemu zachowaniu (na przykład mecz, w którym gracze są postrzegani przez widza jako jednoznaczni agresorzy, a nie jako osoby wykazujące zachowania agresywne, będące tylko elementem sportowej rywalizacji);

- percepcja i zapamiętanie pozytywnych konsekwencji agresywnego zachowania (znaczący element nagrody i braku kary);

- niepokazywanie, że akty agresji to coś „złego”, ukazywanie agresji jako uprawnionej, niezasługującej na naganę/karę;

- niedostrzeganie, że akty agresji są zazwyczaj w swoich konsekwencjach nieodwracalne, powodują faktyczny ból i ewentualne obrażenia;

- identyfikowanie się z osobą agresora prezentowanego jako atrakcyjny, potężny, posiadający atrybuty władzy, czasami wręcz kochany, uroczy i podziwiany;

- brak umiejętności zdystansowania się oglądającego od agresji - na przykład filmy D3: silny „atak” na zmysły widzów znosi świadomość fikcyjności obrazu i potęguje koncentrację na jego treściach agresywnych.

Kończąc rozważania na temat teorii społecznego uczenia się, należy stwierdzić, iż wiele danych potwierdza, że zachowania oparte na agresji są nabywane, wywoływane, podtrzymywane oraz wygaszane w zależności od stosowanych wzmocnień (kar, braku reakcji, nagród), a czynnikiem determinującym są tutaj zarówno doświadczenie własne jednostki, jak i obserwacje doświadczeń innych (Wojciszke, 2007).

\section{ZAKOŃCZENIE}

Spór dotyczący genezy zjawiska agresji odnosi nas do fundamentalnego pytania stawianego przez filozofię: czy natura ludzka jest czymś trwałym i niezmiennym, czy może w wyniku rozwoju ludzkość podlega ciągłemu doskonaleniu i w przyszłości ma szansę wyzbycia się agresji o destruktywnym charakterze? Być może, jak sugeruje Fromm w swych rozważaniach na temat ludzkiej destrukcyjności, prawda leży gdzieś pośrodku:

Człowiek nie jest ani zły, ani dobry. Jeżeli ktoś wierzy w dobroć człowieka jako w jedyną jego potencjalność, w sposób konieczny przywdzieje różowe okulary optymizmu i w efekcie przeżyje bolesne rozczarowanie. Jeżeli ktoś natomiast wierzy w skrajność przeciwną, skończy jako cynik i będzie ślepy na postrzeganie dobra u innych i u siebie. 
Realistyczny punkt widzenia to dostrzeganie obydwu tych możliwości jako realnych potencjalności i badanie, jakie są warunki sprzyjające rozwojowi jednej z nich (Fromm, 2015: 146).

W podobnym duchu co Fromm wypowiadają się Arnold Buss i Mark Perry (Buss \& Perry, 1992; Heitzman, 2002), którzy przyjmują, iż o wystąpieniu i sile agresji decyduje szereg okoliczności. Autorzy wymieniają następujące czynniki: - wrodzone dyspozycje biologiczne - związane głównie z cechami temperamentu;

- wcześniejsze doświadczanie przez jednostkę wpływu zmiennych wywołujących gniew i poprzedzających agresję, takich jak: atak, frustracja, drażniące i nieprzyjemne bodźce oraz trudne sytuacje związane $\mathrm{z}$ doświadczaniem krzywdy lub przemocy;

- pozytywne wzmocnienie (nagradzanie) reakcji agresywnych - związane ze spadkiem napięcia po ujawnieniu reakcji agresywnej (nagroda ma wtedy charakter „wewnętrzny”), eliminacją źródła frustracji czy zaspokojeniem własnych celów (wzmocnienia „zewnętrzne”);

- obserwowanie zachowań agresywnych u innych, uczenie się ich przez naśladownictwo, system nagród i kar oraz spostrzeganie jako skutecznych metod rozwiązywania problemów;

- wzmocnienie społeczne związane z aprobatą grupy (stanowiące zdaniem autorów jedno $\mathrm{z}$ najefektywniejszych wzmocnień) dostarczającej wzorców agresywnych reakcji oraz ułatwiającej wyzwalanie agresji u swych członków. Podsumowując przegląd wybranych teorii dotyczących natury i źródeł agresji, można stwierdzić, że spór pomiędzy badaczami jest nadal nierozstrzygnięty. Udzielenie jednoznacznej odpowiedzi na pytanie, czy agresja jest biologicznie zdeterminowana cechami gatunku ludzkiego, czy też powstaje w wyniku warunków środowiskowych, w tym frustracji i deprywacji potrzeb człowieka, na tym etapie wydaje się niemożliwe. Choć zatem zaprezentowane na gruncie opracowania teorie nie posiadają waloru uniwersalności, powinny być punktem wyjścia dla podejmowanych dalszych rozważań teoretycznych i badań empirycznych w zakresie zachowań agresywnych.

\section{BIBLIOGRAFIA}

Aronson, E. (1995). Człowiek istota społeczna. (Przeł. J. Radzicki). Warszawa: Państwowe Wydawnictwo Naukowe.

Ashley Montagu, M.F. (1950). On being buman. New York: H. Schuman.

Baczko, B. (2009). Rousseau: samotność i wspólnota. Gdańsk: Słowo/obraz terytoria.

Bandura, A. (1973). Aggression. A social learning analysis. Englewood Cliffs: Prentice Hall.

Bandura, A. (2007). Teoria społecznego uczenia się. (Przet. J. Kowalczewska \& J. Radzicki). Warszawa: Wydawnictwo Naukowe PWN. 
Berkowitz, L. (1988). Frustration, appraisals, and aversively stimulasted aggression. Aggresive Behaviour, 14, 3-12.

Buss, A. (1961). The psychology of aggression. New York: Wiley.

Buss, A. \& Perry, M. (1992). The aggression questionnaire. Journal of Personality and Social Psychology, 63, 452-459.

Coffer, C. \& Appley, M. (1972). Motywacja: teoria i badania. (Przeł. K. Rosner, P. Graff, \& J. Radzicki). Warszawa: Państwowe Wydawnictwo Naukowe.

Dollard, J., Miller, N.E., Doob, L., Mowrer, O.H., \& Sears, R.S. (1961). Frustration and aggression. New Haven: Yale University Press.

Drabiński, M. (2019). Piotr Kropotkin i ewolucyjne źródła moralności. Etyka, 58(2), 26-49.

Frączek, A. (1979). Studia nad psychologicznymi mechanizmami czynności agresywnych. Wrocław: Ossolineum.

Frączek, A. (2002). O naturze i formowaniu się psychologicznej regulacji agresji interpersonalnej (s. 45-64). W: I. Kurcz \& D. Kądzielawa (Red.). Psychologia czynności. Nowe perspektywy. Warszawa: Wydawnictwo Naukowe Scholar.

Freud, Z. (1975). Poza zasada przyjemności. (Przeł. J. Prokopiuk). Warszawa: Państwowe Wydawnictwo Naukowe.

Freud, Z. (2020). Wstęp do psychoanalizy. (Przeł. S. Kempnerówna \& W. Zaniewicki). Warszawa: Państwowe Wydawnictwo Naukowe.

Fromm, E. (1998). Anatomia ludzkiej destrukcyjności. (Przeł. J. Karłowski). Poznań: Wydawnictwo Rebis.

Fromm, E. (2015). Serce człowieka. (Przeł. R. Saciuk). Kraków: Wydawnictwo Vis-à-vis/Etiuda.

Gaberle, A., Błachut, J., \& Krajewski, K. (2000). Kryminologia. Gdańsk: Info Trade.

Haś, A. (2008). Struktura agresywności a wybrane osobowościowe korelaty zachowań przestępczych dorostych kobiet. Niepublikowana praca doktorska. Kraków: Uniwersytet Jagielloński.

Heitzman, J. (2002). Stres w etiologii przestępstw agresywnych. Kraków: Wydawnictwo Uniwersytetu Jagiellońskiego.

Hobbes, T. (1954). Lewiatan. (Przeł. Cz. Znamierowski). Warszawa: Wydawnictwo Naukowe PWN.

Hołyst, B. (2016). Kryminologia. Warszawa: Wolters Kluwer.

Krahé, B. (2006). Agresja. (Przeł. J. Suchecki). Gdańsk: Gdańskie Wydawnictwo Psychologiczne.

Kropotkin, P. (1921). Pomoc wzajemna jako czynnik rozwoju społeczeństw. (Przeł. J. Hempel). Warszawa: Wydawnictwo Księgarni Społecznej „Książka”.

Kropotkin, P. (1949). Etyka: Pochodzenie i rozwój moralności. (Przeł. J. Bornstein). Łódź: Słowo.

Kubacka-Jasiecka, D. (2010). Przestępcza agresja nieletnich jako zjawisko rozwojowe - charakterystyka wskaźników diagnostycznych (s. 131-148). W: B. Gulla, I. Niewiadomska, \& M. Wysocka-Pleczyk (Red.). Białe plamy w psychologii sądowej. Kraków: Wydawnictwo Uniwersytetu Jagiellońskiego.

Legowicz, J. (1967). Zarys bistorii filozofii. Warszawa: Wiedza Powszechna.

Lorenz, K. (1972). Tak zwane zło. (Przeł. A. Tauszyńska). Warszawa: Państwowy Instytut Wydawniczy.

MacIntyre, A. (2000). Krótka bistoria etyki. Filozofowie moralności od czasów Homera do XX wieku. (Przeł. A. Chmielewski). Warszawa: Wydawnictwo Naukowe PWN.

Paterek, W. (2001). Stan badań nad przemocą (w literaturze polskiej dekady lat 90.) (s. 77-88). W: R. Borkowski (Red.). Agresja i przemoc. Kraków: Oficyna Wydawnicza Abrys.

Pisula, W. (2007). Psychologia ewolucyjna (t. 1, s. 179-204). W. J. Strelau (Red.). Psychologia. Podręcznik akademicki. Gdańsk: Gdańskie Wydawnictwo Pedagogiczne.

Poznaniak, W. (2001). Psychospołeczne skutki przemocy występującej w grach elektronicznych. Ruch Prawniczy, Ekonomiczny i Socjologiczny, 63(1-2), 205-219. 
Przybysz-Zaremba, M. (2015). Egzemplifikacje wybranych teorii zachowań agresywnych człowieka - perspektywa trójwymiarowa. Studia nad Rodzina, 2(37), 311-332.

Ranschburg, J. (1993). Lęk, gniew, agresja. (Przeł. M. Schweinitz-Kulisiewicz). Warszawa: Wydawnictwa Szkolne i Pedagogiczne.

Rousseau, J.J. (1966). Umowa społeczna. (Przeł. B. Baczko). Warszawa: Państwowe Wydawnictwo Naukowe.

Stach, R. (1989). Zachowania agresywne. Wrocław-Warszawa-Kraków-Gdańsk-Łódź: Zakład Narodowy Imienia Ossolińskich/Wydawnictwo Polskiej Akademii Nauk.

Stanik, J.M., Roszkowska, A., \& Kucharewicz, J. (2006). Psychologiczna diagnoza zachowań agresywnych w świetle badań Skalą Agresji Buss-Durkee (SABD) - wyniki badań i normalizacja testu (s. 81-100). W: J. M. Stanik (Red.). Zastosowanie wybranych technik diagnostycznych w psychologicznej praktyce klinicznej i sqadowej. Katowice: Wydawnictwo Uniwersytetu Sląskiego.

Terelak, J. (2001). Psychologia stresu. Bydgoszcz: Oficyna Wydawnicza Branta.

Wojciszke, B. (2007). Relacje interpersonalne (t. 3, s. 147-164). W: J. Strelau (Red.). Psychologia. Podręcznik akademicki. Gdańsk: Gdańskie Wydawnictwo Psychologiczne.

Wolska A. (2002). Model czynników ryzyka popetnienia przestepstwa agresywnego (= Rozprawy i Studia, t. (DVI) 432). Szczecin: Wydawnictwo Naukowe Uniwersytetu Szczecińskiego.

Ziółkowski, J. (2015). Polityka wrogości a ludzkie zoo - rozważania o biologicznej genezie agresywności w polityce. Studia Politologiczne, 5(37), 108-129. 